Original article

\title{
Development of a new branchiness index AsIX - A simple tool to describe branchiness in young deciduous forest stands
}

\author{
Gerhard Struck and Achim Dohrenbusch* \\ Institute of Silviculture, Department I: Silviculture of the Temperate Zones and Forest Ecology, \\ University of Göttingen, Büsgenweg 1, 37077 Göttingen, Germany
}

(Received 6 September 1999; accepted 24 March 2000)

\begin{abstract}
Description of young tree's quality is difficult, in particular there is no adequate and easy applied method to describe branchiness. The following contribution describes the development of a new index to estimate the branch's diameter influence on tree quality. On the base of the measurement of 2520 young oak trees (22 years old), the branchiness index, AsIX, was created as the ratio between the branch of the largest diameter and the tree's diameter at breast height (DBH). The idea was that a same diameter of branches is worse for small trees than for bigger ones. In a very wide range of plant densities, no influences of the different initial densities on the AsIX values were found. Trees in wider plantations with a higher branch diameter had as good AsIX-values than trees in denser plantations with a lower branch diameter. But, however, an influence of different site conditions on the AsIX was noticed. AISX was better within better site conditions compared to worse site conditions. It is concluded that the description of branchiness using this ratio is better than the use of absolute diameter values. AsIX integrates the stands growth potential in terms of DBH. The use of this index avoids the overestimation of branch-thickness for trees with a high growth potential. Due to a lack of literature dealing with branch-ratios, there are no comparisons to other indices in the discussion.
\end{abstract}

branchiness / index / stand density / deciduous forests / quality / Quercus

Résumé - Développement d'un nouvel indice de branchaison «ASIX» : un outil simple pour décrire la branchaison dans de jeunes peuplements de forêts décidues. La description de la qualité de jeunes arbres est difficile, en particulier il n'existe pas de méthode facile et adéquate pour décrire la branchaison. La contribution suivante décrit le développement d'un nouvel indice pour estimer l'influence du diamètre des branches sur la qualité de l'arbre. Sur la base de mesures de 2520 jeunes chênes (âgés de 22 ans), l'indice de branchaison, «ASIX», a été créé comme étant le rapport entre le diamètre de la branche la plus grosse et le diamètre à hauteur de poitrine $(\mathrm{DBH})$. L'idée est que, à diamètre identique, les arbres les plus petits sont les moins bons. La densité initiale du peuplement n'a pas d'influence sur les valeurs calculées de l'indice ASIX. Les arbres des plantations les moins denses, avec des diamètres de branches plus élevés, ont une valeur de l'indice aussi bonne que celle des plantations moins denses avec des diamètres de branches inférieurs. Les conditions du milieu influent cependant sur la valeur de cet indice. ASIX est meilleur lorsque les conditions stationnelles sont bonnes. On conclut que la description de la branchaison par cet indice est meilleure que l'usage de la valeur absolue du diamètre. ASIX intègre le potentiel de croissance en terme de DBH. L'usage de cet indice évite les surestimations de la taille des branches sur les arbres à fort potentiel de croissance. En raison du manque de bibliographie dans ce domaine d'indice rapport de branche, il n'y a pas de comparaison avec d'autres indices dans la discussion.

branchaison / indice / densité du peuplement / forêts décidues / qualité / Quercus

* Correspondence and reprints

Tel. (49) 5513936 78; Fax. (49) 5513921 70; e-mail: adohren@gwdg.de 


\section{INTRODUCTION}

The objective description of young tree's quality in deciduous forests is still difficult, in particular within forest investigations $[1,28]$. Tree quality is often estimated by the use of categorical variables $[6,8,9,24$, 28].

One main factor influencing the trees' quality is the diameter of branches. This feature is mainly assessed by the measurement of absolute branch diameter [7, 10, 16, $21,25,26,27]$. But the comparison of absolute branch thickness of differently treated stands does not consider the growth potential of the trees. Harmer [14] points out that vigorous trees often carry heavy stem branches that reduce timber quality, whereas less vigorous trees have smaller branches but are often of bad growth.

But does a branch of certain diameter influence the tree quality of good and bad growing trees in the same way? Certainly not. Due to this, there is a need of easily to measure parameters to describe the branch-diameter effect on tree quality under consideration of the individual growth potential.

Following the ideas of Kramer [17] and Mayer [20], which created different crown-indices, the following article describes the development of a branchiness index (AsIX) on interval scale.

This could be a method to describe the influence of branches on tree quality under consideration of the individual growth potential of each tree.

\section{MATERIALS AND METHODS}

Base of this investigation are 2520 22-year-old oaks, which were measured on 24 experimental plots located in the forest district Fuhrberg near Hannover [28]. This region in north-western Germany is characterised by a subatlantic climate with an annual precipitation of $700 \mathrm{~mm}$ and a mean annual temperature of $14.5^{\circ} \mathrm{C}$. The soil is a poor sandy pleistocene podsolic cambisol (FAO). The plots have been afforested in 1976 using three different densities and two year old seedlings. The oaks were 24 years old at the date of measurement. The three different initial densities were very high compared to actual plantation densities. The current density within the stand is still very high and the differences between the initial densities are also obvious (table I).

Before afforestation, the whole logging slash including the humus layer was pushed on ramparts using bulldozers. Due to this practice a gradient of different nutrient situations can be noticed on the plots. The growth potential of trees was considerably higher close to the ramparts compared to potential of plants in a greater distance [29]. This experimental design was very suitable to investigate branchiness of young trees under different yield situations.

To detect the effects of initial density and logging slash removal, the following features were measured on 105 trees $[28,29,30]$ :

- Tree height;

- DBH;

- Branch of the largest diameter within in the first $2.5 \mathrm{~m}$ height. Branch thickness was measured, at right angles to the branch, $2 \mathrm{~cm}$ apart from the stem-insertion with digital slide-gauge. Living branches only were considered.

\section{RESULTS}

Tree height showed a reaction to the nutrition gradient. In the "wide spaced" plantations, trees in a distance of $12 \mathrm{~m}$ to the humus ramparts reached only $75 \%$ of the height of trees directly beside the ramparts. In the "medium spaced" and "narrow spaced" plantations, the height growth decreased to about $50 \%$ compared to the trees close to the ramparts. The rampart's effect on the tree height was greater, with higher plant-density (figure 1).

The DBH decreased for all initial densities, with a distance of $6 \mathrm{~m}$ from the rampart. As already mentioned for height, the effect on the DBH increased with higher plantation density. Compared to the height, DBH was affected less. Figure 2 furthermore shows that mean $\mathrm{DBH}$ was greatest for the "wide spaced" plantation

Table I. Different initial densities of the experimental plots.

\begin{tabular}{|c|c|c|c|}
\hline Spacing & Plants per ha & Current density & Characterisation \\
\hline $1.4 \mathrm{~m} \times 0.3 \mathrm{~m}$ & 23810 plants ha ${ }^{-1}$ & 19700 plants ha ${ }^{-1}$ & "narrow spaced" \\
\hline $1.4 \mathrm{~m} \times 0.5 \mathrm{~m}$ & 14826 plants ha ${ }^{-1}$ & 12464 plants ha ${ }^{-1}$ & "medium spaced" \\
\hline $1.4 \mathrm{~m} \times 0.8 \mathrm{~m}$ & 8928 plants ha ${ }^{-1}$ & 7455 plants ha ${ }^{-1}$ & "wide spaced" \\
\hline
\end{tabular}



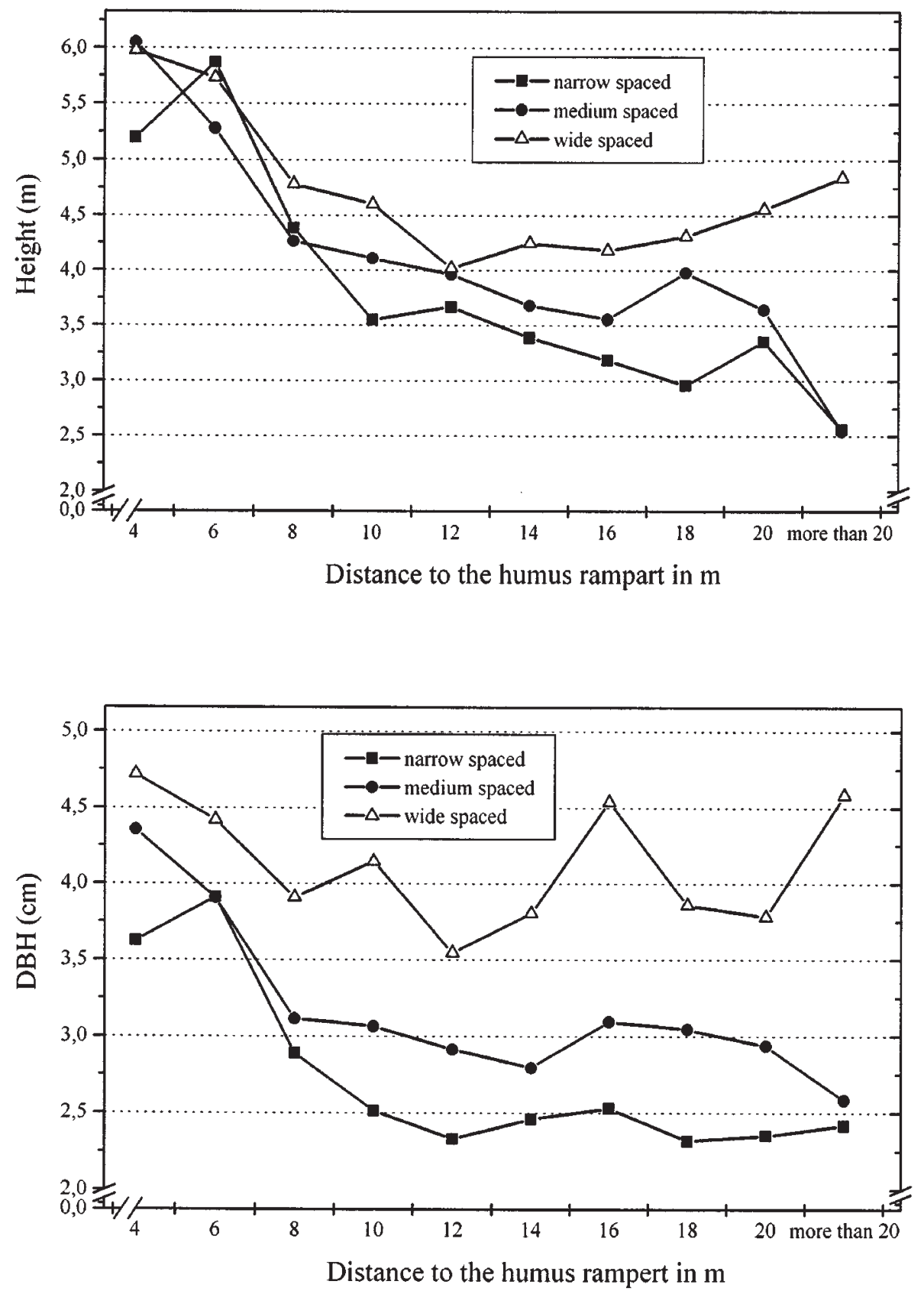

Figure 1. Effect of the humus rampart distance on the mean height in the different initial densities.
Figure 2. Effect of the humus rampart distance on the mean $\mathrm{DBH}$ for the different initial densities. followed by the "medium" and finally the "narrow spaced" plantation .

As a result of less competition, the growth potential of individual trees was higher for the "wide spaced" plantation.

In the "wide space" plantation, the branch thickness was greater compared to the other densities. Branches in the wide spaced plantations had a mean diameter of about $1.5 \mathrm{~cm}$, whereas the branch-diameter in the medium spaced plantation $(1.3 \mathrm{~cm})$ did not differ significantly from the narrow spaced plantation $(1.2 \mathrm{~cm})$.

Within the same plantation density, the branch thickness was equal even in different distances to the humus rampart. Trees with a low height and a low DBH had 
branches as thick as good growing trees close to the ramparts. Hence, the nutrition gradient seemed not to influence the branch diameter. Struck [28] showed that neither the mean branch diameters were influenced by the rampart distance, nor the extreme values. He found as heavy branches near the ramparts as in a distance of more than $20 \mathrm{~m}$ (figure 3).

A significant correlation between branch thickness of the biggest branch and the DBH $(r=0.5)$ was found. But the value dispersion was to high to create a successful regression between the parameters.

This result pointed out that, on the one hand, there were small trees with comparable big branches and on the other side large trees with comparable small branches.

Assuming that the quality of a good growing tree, in comparison to a bad growing tree, is affected less by a branch of equal thickness, the growth potential has to be integrated in the model to describe the effect of branchiness on tree quality. The branchiness index (ASIX) was accordingly calculated for each single tree ${ }_{i}$ as follows:

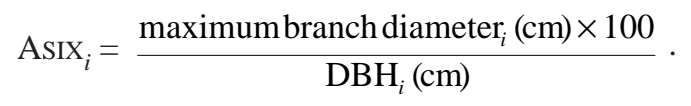

The AsIX-value describes the branch thickness of a tree as the percentage of its DBH. Using this method, the description of branch thickness is weighted with the growth potential. The tree's quality decreases with an increasing AsIX-value.

Figure 4 shows the development of the AsIX in dependence on the ramparts distance exemplary for the "narrow spaced" plantation.

The branches grew thicker in relation to the $\mathrm{DBH}$ with a growing rampart distance. Therefore, tree quality decreases.

If the different plantation densities were compared on the base of the AsIX, a different result is found compared to the analyses of absolute branch thickness. The branchiness indexes of the different initial densities do not differ significantly. The distributions of the values are almost identical as well. Merely the "wide spaced" plantation shows a smaller value-dispersion.

Even, the median value shows that tree quality, measured by the ASIX value, for the "narrow spaced" plantation is worse than for the other densities. This is the result of bad DHB-growth on the "narrow spaced" plantation. It is conspicuous that the wide space plantation does not reach AsIX-values of more than $85 \%$. Due to the good DBH-growth the tree quality for this plantation density is affected less by the absolute thicker branches (figure 5).

Mean values of the whole collective are of less interest for the estimation of the young stand's quality. The future economical value of the young stands is formed by the future crop trees. These trees will be normally

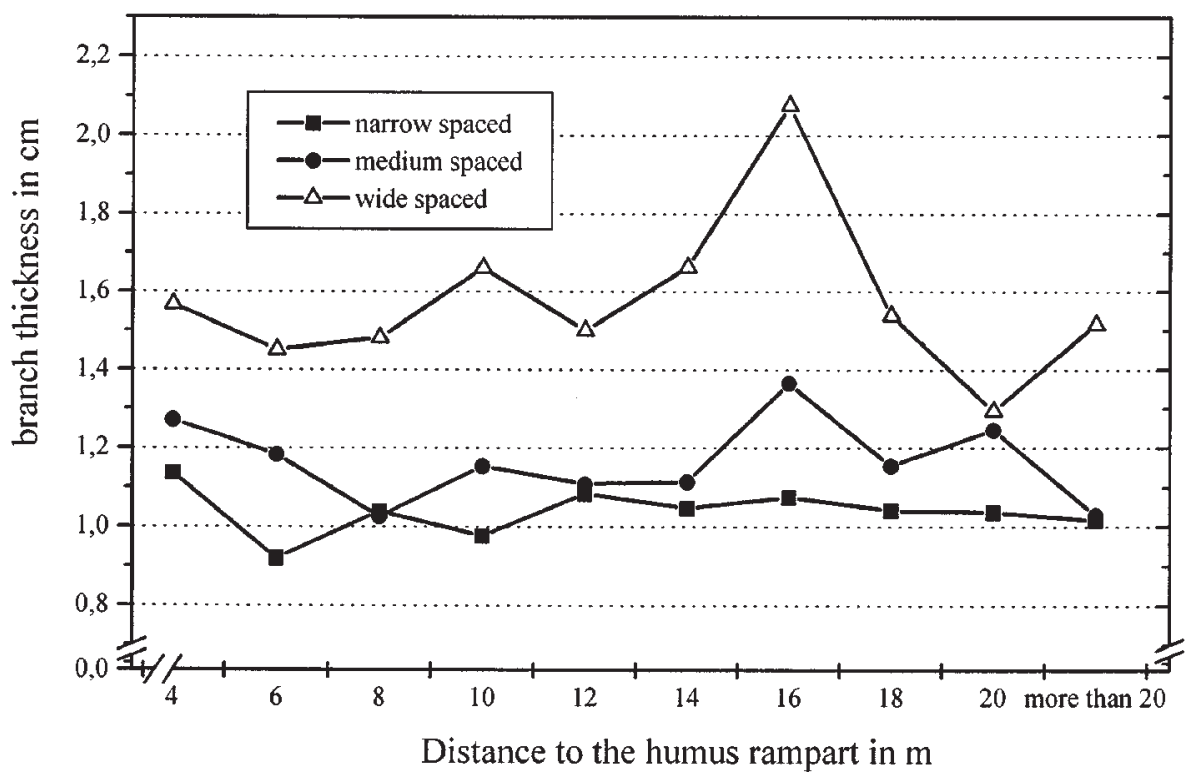

Figure 3. Effect of the humus rampart distance on branch thickness for the different initial densities. 

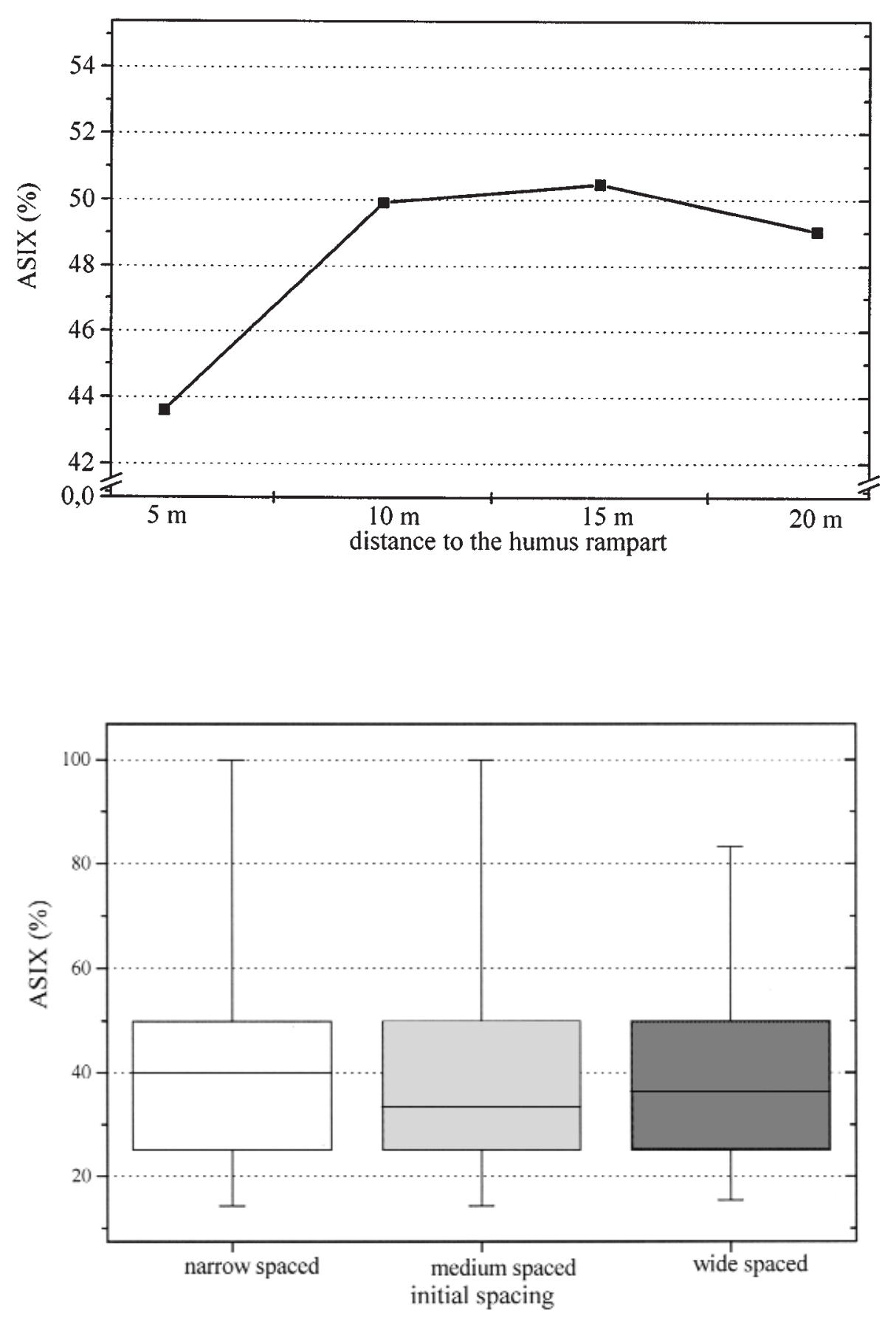

Figure 4. Effect of the nutrient gradient on the development of branchiness index (narrow spaced plantation).
Figure 5. Box Wisker plot for the branchiness index of the different densities. selected from the $20 \%$ biggest trees of a stand. Cause our measurement included 840 trees per different density, the following results refer to 170 future crop trees in each density.
It is obvious considering this collective, that the AsIX is slightly better for the "narrow spaced" plantation compared to the other densities (figure 6). 


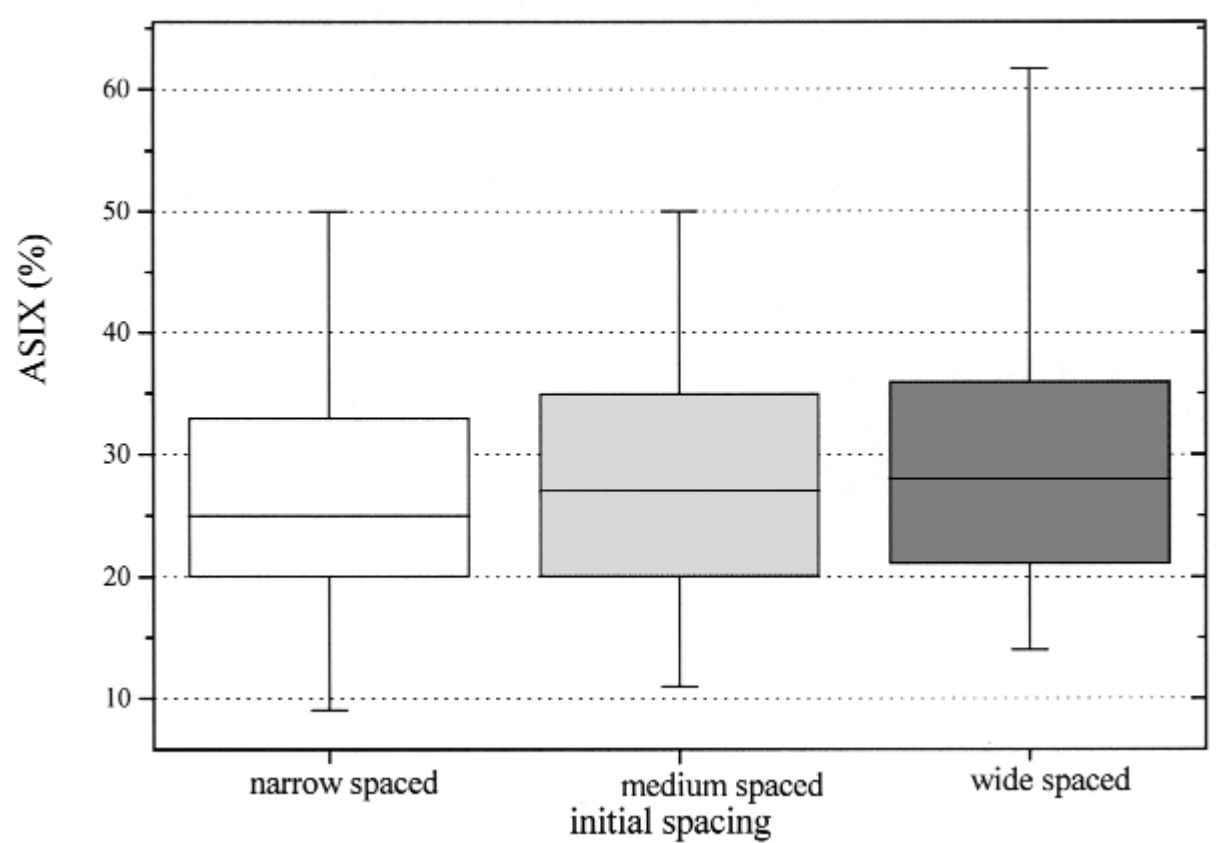

Figure 6. Box Wisker plot for the branchiness index in the different densities for the $20 \%$ biggest trees.
Using this index and considering a certain value for the AsIX, it is shown how the branch thickness could increase without detecting a decrease in quality. Therefore the equation for the AsIX-calculation is changed to:

$$
\text { maximum branch thickness }_{i}(\mathrm{~cm})=\frac{\operatorname{ASIX} \times \mathrm{DBH}_{i}(\mathrm{~cm})}{100}
$$

If the silvicultural aim is an ASIX of up to $50 \%$, the branch thickness should have been increased from $2.54 \mathrm{~cm}$ in the "narrow plantation" to $3.47 \mathrm{~cm}$ in the "wide plantation" without any decrease in tree quality (table II).

If the silvicultural aim is a certain maximum AsIX, the mean increment of branch thickness without a loss of future tree quality, can be calculated. The AsIX is able to quantify the influences of different densities on the branch quality under consideration of the stand growth potential. The results show that the calculation of the AsIX could be method to detect influences of thinning age and thinning grade on tree quality. This application of AsIX should be tested in further investigations. The AsIX-method enables the user to note relative changes in branch quality.

\section{DISCUSSION}

Unbiased estimation of quality in young deciduous forest stands is a problem. In practice, the trees are selected by individual preferences of foresters. But science, as well, lacks objective and easy methods to estimate tree quality. Hakkila [12] and Hakkila et al. [13] used similar indices to AsIX to estimate branch amount

Table II. Calculation of branch thickness with a special Asix.

\begin{tabular}{lccc}
\hline Initial spacing & $\begin{array}{c}\text { Silvicultural desired } \\
\text { Asix }\end{array}$ & $\begin{array}{c}\text { DBH 20\% } \\
\text { biggest trees }\end{array}$ & $\begin{array}{c}\text { Calculated branch } \\
\text { thickness }\end{array}$ \\
\hline "narrow spaced" & 50 & $5.09 \mathrm{~cm}$ & $2.54 \mathrm{~cm}$ \\
"medium spaced" & 50 & $5.81 \mathrm{~cm}$ & $2.91 \mathrm{~cm}$ \\
"wide spaced" & 50 & $6.97 \mathrm{~cm}$ & $3.48 \mathrm{~cm}$ \\
\hline
\end{tabular}


as a raw material source. But we found no similar quotients to ASIX with the aim to describe tree quality.

Categorical variables have been mainly used [1, 7, 9, $28]$. Hence, the comparison of different investigations using categorical features is difficult, because the estimation depends on subjective impressions [9]. The results differ from person to person even if the same stands are surveyed. These kind of disadvantages caused by using categorical variables can be avoided by the use of features on interval scales. These interval scale variables must be created so that the results are independent from the measuring person. For this reason, forest scientists prefer the comparison of absolute branch thickness. The disadvantage of this method is that the different yield potentials of the stands cannot be considered.

It is pointed out in many investigations, that trees, which grew in "wide spaced" plantations are of worse quality than trees growing in dense stands, because branch thickness increases with an increase in individual space $[7,10,16,21,24,25,26,27,28]$. The current investigation showed the same results:

The oaks' branches were thicker with decreasing initial density but not thicker with worse site conditions $[28,29,30]$. The site gradient effects are discussed by Struck [28]. He did not find any influences on branch architecture. Large branches were found in each different distance to the humus ramparts.

However, it should be considered that plants having more space to grow have better DBH growth $[2,10,11$, $17,24,26]$.

The rare at which branches are occluded is also important in determining wood quality. In most cases, branches will be overgrown faster in wide space plantations. Niemisto [23] reports that the self-pruning process of dead branches may be slowed down in very dense stands. Becker et al. [2] point out that thicker branches have no influences on the quality, if these branches would be overgrown faster, and the better youth growth leads to the development of relatively fine wood. Grünebaum et al. [11] investigated oaks from a wide space plantation and noticed that the faster youth growth did not lead to worse inner wood quality. It is therefore clear that an analysis of the absolute branch thickness, only, in differently treated stands is not enough to estimate their future quality. Scientists do not know which supposed tree defects will disappear in the stand's future life. The estimation of branchiness and its effect in later ages is difficult.

In the literature one can find a large amount of models dealing with branchiness (for example, $[3,4,5,14,18$, 19, 22]). Mainly, the intention of such investigations is the prediction of the development of architecture under different silvicultural systems and they deal with coniferous species. The development of AsIX had not the aim to create another architectural model. The AsIX values are proposed as an additional, very easy, tool to describe and compare tree quality. The periodical comparison of the AsIX-values is able to detect the influences of different silvicultural treatments on the branch quality. It is clear, that the diameter of the largest branch is not the only factor responsible for the future value of a tree. Amount of branches on the trunk is also very important.

It is possible to create other indices on the base of AsIx to avoid these problems: For example, it is possible not only to use the diameter of the largest branch but also to calculate a mean value of several branches. It is furthermore conceivable to weigh the AsIX-value with the number of branches on a special bole length. A tree with a high number of little branches does therefore not automatically have a better quality than a tree with only one or two big branches. The emphasis on a certain bole length further integrates the fact that branches in a special insertion height (for example more than $10 \mathrm{~m}$ ) did not influence the quality at all.

The AsIX is only an attempt to define a value, which allows an objective estimation of quality in young deciduous stands. Naturally, appearing branches and their thickness are an important quality defect if the trees should be sold. The estimation of tree quality using the AsIX in old forests is less successful because branches on trunks to be sold are always defects and independent from the trees DBH. The use of the AsIX should be concentrated on young stands up to polewood age. The expected branch-free bole length should be reached at this age and the stem defects of the young stands should be obscured by growth, in particular for the crop trees. In most cases, silvicultural goal is a certain branch free bole length. Branches inserting higher than this length are of less interest. Trees with a good growth potential should reach this silvicultural aim in a shorter time, even if the branches grew thicker. Asix-values may help to avoid the overestimation of branchiness for the future quality development, because this index integrates the growth potential.

The AsIX is not able to compensate the measurement of branch diameters, but the comparison of differently treated stands is easier using this method. It is very important that quality described by the AsIX is not only a value for absolute branch diameters but considers the individual tree growth potential. 


\section{REFERENCES}

[1] Anonymus, Begründung von Eichenbeständen durch Nesterpflanzung. Procceding of a meeting with the aim to equalize the investigation parameters in young oak high forests. Lower Saxony Forest Research Station, Göttingen, unpublished, 1995.

[2] Becker G., Hapla F., Teutenberg A., Untersuchungen der Holzqualität von Traubeneichen aus unterschiedlich dicht begründeten Beständen, Holz als Roh- und Werkstoff 48 (1990) 339-343.

[3] Bertram J.E.A., Size dependant differential scaling in branches: the mechanical design of trees revisited, Trees 4 (1989) 241-253.

[4] Brown A.G., Doran J.C., Variation in growth and branching characters of Pinus attenuata, Silvae Genet. 34 (1985), 100-104.

[5] Colin F., Houllier F., Branchiness of Norway spruce in north-eastern France: modelling the vertical trends in maximum nodal branch size, Ann. Sci. For. 48 (1991) 679-693.

[6] Dippel M., Wuchsleistung und Konkurrenz von Buchen/Lärchen-Mischbeständen im südniedersächsischen Bergland, Diss. Forstwiss. Fachb. Univ. Göttingen, 1989.

[7] Erteld W., Verbandweite, Jahrringbreite und Aststärke der Kiefer auf einem mittleren terrestrischen Standort im Altpleistozän, Soz. Forstw. 28 (1978) 242-245.

[8] Fischer H., Acker- Erstaufforstungen - Bestandesbegründung, Wachstum und Ökologie an Fallbeispielen, Hainholz Verlag, Göttingen, 1998.

[9] Gadow K.V., Zur Bestandesbeschreibung in des Forsteinrichtung, Forst und Holz 48 (1993) 602-606.

[10] Gaul H.T., Stüber V., Der Eichen-NelderVerbandsversuch Göhrde, Forst und Holz 51 (1996) 70-75.

[11] Grünebaum M., Teutenberg-Raupach A., Paul C., Ein Weitverband bei Traubeneiche - Auswirkungen auf Wachstum, Schnittholzqualität und Furniereignungen, Forst und Holz 48 (1993) 3-7.

[12] Hakkila P., Coniferus branches as a raw material source, Communicationes Institute Forestalis Fenniae 75 (1971) 1.

[13] Hakkila P., Laasasenaho J., Kariottinen J., Branch data for logging work, Instituti Forestale Fenniae, Helsinke, Folia Forestalia 147 (1972).

[14] Harmer R., Relationship between Shoot Length, Bud Number and Branch Production in Quercus petraea (Matt.) Liebl., Forestry 65 (1992) 61-72.

[15] Inglis C.S., Cleland M.R., Predicting final branch size in thinned radiata pine stands, FRI-Bulletin, Forest Research Institute, New Zealand 3 (1982) 17.
[16] Kenk G., Auswirkungen von DouglasienPflanzverbänden auf Aststärken und Vornutzung sowie Überlegungen zur Ästungshöhe, Allg. Forst- und Jagdztg. 152 (1981) 168-180.

[17] Kramer H., Waldwachstumslehre, Verlag Paul Parey, Hamburg und Berlin, 1988.

[18] Mäkinen H., Colin F., Predicting branch angle and branch diameter of Scots pine from usual tree measurements and stand structural inforamtion, Can. J. For. Res. 28 (1998) 1686-1696.

[19] Matziris D.I., Variation in Growth and Branching Characters in black Pline (Pinus nigra Arnold) of Peleponneesos, Silvae Genet. 38 (1989) 77-81.

[20] Mayer R., Kronengröße und Zuwachsleistung der Traubeneiche auf süddeutschen Standorten, Allg. Forst- und Jagdztg. (1958) 105-114, 151-163, 191-201.

[21] Melzer E.W., Brunn E., Netzker D., Pflanzverband und Kulturqualität bei Kiefer, Forstarchiv 63 (1992) 136-142

[22] Meredieu C., Colin F., Hervé J-C., Modelling branchiness of Cosican pine with mixed-effect models (Pinus nigra Arnold ssp. laricio (Poiret) Maire), Ann. Sci. For. 55 (1998) 359-374.

[23] Niemisto P., Influence of initial spacing and row to row distance on the crown and branch properties and taper of silver birch (Betula pendula), Scan. J. For. Res. 10 (1995) 235-244.

[24] Schaper C., Das Jungendwachstum von Stiel- und Traubeneichen auf norddeutschen Standorten, Diss. Forstwiss. Fachb. Univ. Göttingen, 1978.

[25] Schmaltz J., Aststärkenentwicklung und Schaftqualität in zwei Kiefernverbands-versuchen, AFZ 44 (1989) $1337-1339$.

[26] Schmaltz J., Fröhlich A., Gebhardt M., Die Qualitätsentwicklung in jungen Traubeneichenbeständen im Hessischen Spessart, Forstarchiv (1997) 3-10.

[27] Spellmann H., Baderschneider A., Erste Auswertung eines Traubeneichen-Pflanzverbands- und Sortimentsversuches im Forstamt Hardegsen/Solling, Forst und Holz 43 (1988) 447-450.

[28] Struck G., Effekte von Pflanzverband, Kulturdüngung und Schlagräumung am Beispiel junger Traubeneichenbestände, Hainholz-Verlag, Göttingen, 1999.

[29] Struck G., Dohrenbusch A., Long term effects of radical removal of logging slash on the growth and quality of young Sessile Oak stands (Quercus petraea Lieth), in: IUFROproceedings: Advances in research in intermediate Oak stands. Institut für Wald wachstum der Univ. Freiburg, 1997, pp. 184-192.

[30] Struck G., Dohrenbusch A., Wirkungen von Pflanzverband und Düngung in jungen Traubeneichenbeständen, AFZ (1998) 772-775. 